\title{
Desain dan Implementasi Sistem Online Gudang Pada PT. PLN (Persero) Distribusi Regional Jawa Tengah dan D.I Yogyakarta
}

\author{
Ervin Adhi Cahyanugraha ${ }^{1)}$, Rizal Isnanto ${ }^{2)}$, Ike Pertiwi Windasari ${ }^{2)}$ \\ Program Studi Sistem Komputer Fakultas Teknik Universitas Diponegoro \\ Jalan Prof. Sudharto, Tembalang, Semarang, Indonesia \\ adhicerv@gmail.com
}

\begin{abstract}
The information system that can provide complete, accurate information in an integrated way with the ability to reach all people in the system is very important. The criteria are not fulfilled by the warehouse management system on PT. PLN (Persero), distribution of Central Java and Special Region of Yogyakarta. Some districts are not reached by the information system technology; some of them still use Microsoft Office Excel to manage the goods in the warehouse. . So, communication up to rayon is not good, rayon and area are so hard to exchange information, transaction between rayon and area is not quick. this case cause procurement goods is hampered, and this make direct impact to unfinished project. Therefore, the online system of this warehouse can solve the flaw of the old system.

The Warehouse Online System is the ASP.Net-based web application. This development process uses Microsoft Visual Studio as the development tools. An information system is not separable from the database as the information data storage; Warehouse Online System uses Oracle as the Relational Database Management System (RDBMS).

The Warehouse Online System is suitable with the Standard Operational Procedure (SOP) of PT. PLN (Persero). Through Warehouse Online System, the distributors from the area or district can be integrated to communicate, to do the transaction on the material in the warehouse, and to get the access of the user based on their task and authority. Based on the Black Box test, the functions on Warehouse Online System function like what is expected. The maintenance process is still needed to improve the system in the future.
\end{abstract}

Keywords: information system, PT. PLN, warehouse, web, database

\section{PENDAhUluan}

$\mathrm{S}$ istem informasi yang dapat menyediakan informasi secara lengkap dan akurat, secara terintegrasi dan luas menjangkau seluruh pelaku sistem merupakan hal yang sangat dibutuhkan. Hal inilah yang menjadi latar belakang dikembangkannya Sistem Online Gudang pada PT. PLN (Persero) Distribusi Jawa Tengah dan D.I Yogyakarta.
Beberapa rayon masih belum terjangkau oleh teknologi sistem informasi gudang, beberapa masih mengandalkan Microsoft Office Excel untuk mengelolanya.

\section{TINJAUAN PUSTAKA}

\section{A. Definisi Sistem}

Sistem adalah interaksi yang sepenuhnya rumit, tidak terdefinisi, dan sukar antara manusia, kelompok manusia, computer dan organisasi. Masalah ini menjadi lebih pelik karena suatu sistem tidak pernah dianggap selesai. Seringkali, status selesainya sistem diberikan lebih karena dapat digunakan pada waktu yang relatif lama. ${ }^{[4]}$ Pengembangan sistem akan dengan cepatnya mencapai angka sembilan puluh lima persen dan tetap Sembilan puluh lima persen selamalamanya, karena tak ada sistem yang sempurna dan selalu terbuka peluang untuk mengembangkan dan mengembangkannnya. ${ }^{[9]}$

\section{B. Definisi Sistem Manajemen Gudang}

Sistem adalah kumpulan interaksi dari sub sistem, manajemen adalah ilmu mengelola sumber daya, sedangkan gudang adalah tempat penyimpanan barang sementara. Secara ringkas sistem manajemen gudang mengandung pemahaman : pengelolaan dari aktifitas yang saling terkait dalam aktifitas penyimpanan barang sementara. Penerimaan dari pemasok, handling barang, pengeluaran barang ke tujuan adalah garis besar dari aktifitas penyimpanan. ${ }^{[7]}$

\section{Perangkat Pemodelan Sistem}

Pemodelan sistem adalah cara formal untuk menggambarkan bagaimana sistem berjalan. Pemakai yang berbeda mungkin akan membutuhkan pemodelan dengan cara yang berbeda pula, perancangan yang berbeda juga membutuhkan yang berbeda pula, demikian juga dengan sistem yang berbeda. ${ }^{[4]}$

Ada dua pendekatan pemodelan sistem, yaitu pendekatan terstruktur dan pendekatan berorientasi objek. Pendekatan terstruktur menggunakan DFD, sedangkan pendekatan berorientasi objek menggunakan pemodelan UML (Unified Modeling Language) sebagai standar metodologi pengembangan sistem informasi. ${ }^{[4]}$ Pada pengembangan Sistem Online Gudang ini melakukan pendekatan 
berorientasi objek dengan UML (Unified Modeling Language) sebagai pemodelan sistem.

\section{$D$. Unified Modeling Language (UML)}

Unified Modeling Language (UML) merupakan bahasa grafis untuk menvisualisasikan, menspesifikasikan, membangun, dan mendokumentasikan sistem perangkat lunak. ${ }^{[3]}$ Unified Modeling Language (UML) adalah himpunan strukturdan teknik untuk pemodelan desain program berorientasi objek (OOP) serta aplikasinya. ${ }^{[6]}$ UML adalah metodologi untuk mengembangkan sistem OOP dan sekelompok perangkat untuk mendukung pengembangan sistem tersebut. ${ }^{[8]}$

\section{E. Pemodelan Data Entity Relationship Diagram (ERD)}

ERD adalah sebuah model data yang mengunakan beberapa notasi untuk menggambarkan data dalam hal entitas dan relasi. ERD sering digunakan sebagai sarana komunikasi antara perancang basis-data dan pengguna sistem selama tahap analisis dari proses pengembangan basis-data dalam kerangka pengembangan sistem informasi secara utuh. ${ }^{[5]}$

\section{F. Framework.NET}

Framework .NET adalah suatu komponen windows yang terintegrasi yang dibuat dengan tujuan untuk mendukung pengembangan berbagai macam jenis aplikasi serta untuk dapat mejalankan berbagai macam aplikasi generasi mendatang termasuk pengembangan aplikasi Web Services XML. ${ }^{[11]}$

\section{G. ASP.NET}

ASP.NET singkatan dari Active Server Pages NET. Bahasa pemrograman ASP.NET oleh Microsoft. ASP.NET digunakan untuk membuat halaman web yang merupakan bagian integral dari Microsoft .NET framework. Sebagai bagian dari .NET, ASP.NET adalah perangkat yang sangat berguna bagi programmer untuk membuat website yang dinamis yang disertai dengan bahasa VB dan C\#. File dot aspx tersebut nantinya akan diproses Internet Information Servises dan .NET framework menjadi bentu elemen-elemen HTML sebelum dikirim ke client untuk ditampilkan pada browser. ${ }^{[14]}$

\section{H. C\#}

C\# adalah bahasa pemrograman baru yang diciptakan oleh Microsoft sebagai bagian dari inisiatif kerangka .NET Framework. C\# dikembangkan dibawah kepemimpinan Anders Hejlsberg yang telah menciptakan berbagai macam bahasa pemrograman termasuk Borland Turbo $\mathrm{C}++$ dan Borland Delphi. Bahasa pemrograman ini dibuat berbasiskan bahasa $\mathrm{C}++$ yang telah dipengaruhi oleh aspek-aspek ataupun fitur bahasa yang terdapat pada bahasa-bahasa pemrograman lainnya seperti Java, Delphi, Visual Basic, dan lain-lain) dengan beberapa penyederhanaan. Seperti halnya bahasa pemrograman yang lain, C\# bisa digunakan untuk membangun berbagai macam jenis aplikasi, seperti aplikasi berbasis windows (desktop) dan aplikasi berbasis web serta aplikasi berbasis web services. ${ }^{[1]}$

\section{Structured Query Language ( $S Q L)$}

Structured Query Language (SQL) adalah sebuah bahasa pemrograman yang digunakan untuk mengakses data dalam basis-data relasional. ${ }^{[10]}$ Kebanyakan perangkat lunak basisdata saat ini menggunakan bahasa SQL, seperti MySQL, SQL server, oracle dan lain sebagainya. ${ }^{[10]}$

\section{$J$. Oracle}

Oracle adalah relational data base management sistem (RDBMS) yang terdiri dari kumpulan data dalam suatu sistem manajemen basis-data. Basis-data merupakan inti dari suatu sistem informasi. Sebuah sistem basis-data yang besar sekali dapat terdiri dari beberapa Oracle server yang berjalan di banyak server yang terpisah. Masing-masing server ini akan mengelola data yang sesuai dengan bagiannya. ${ }^{[13]}$

\section{PERANCANGAN SISTEM}

\section{A. Analisis Masalah}

Analisis masalah dilakukan untuk mengetahui permasalahan yang dihadapi. Hasil dari analisis dapat menjadi standar dari spesifikasi sistem untuk menghadirkan solusi. Beberapa masalah yang harus dipecahkan oleh Sistem Online Gudang ditunjukkan pada Tabel 1.

TABEL 1

TABEL ANALISIS MASALAH

\begin{tabular}{|c|c|c|}
\hline No. & Masalah & Penyebab \\
\hline 1 & $\begin{array}{l}\text { Terdapat banyak material } \\
\text { stok lama pada gudang rayon } \\
\text { dan tak kunjung dipakai }\end{array}$ & $\begin{array}{l}\text { Tidak ada regulasi standar } \\
\text { dalam proses retur barang }\end{array}$ \\
\hline 2 & $\begin{array}{l}\text { Data tidak akurat, } \\
\text { kemungkinan besar barang } \\
\text { hilang atau pemakaian yang } \\
\text { tanpa sepengetahuan }\end{array}$ & $\begin{array}{l}\text { Sistem lama tidak melakukan } \\
\text { pengawasan secara ketat }\end{array}$ \\
\hline 3 & $\begin{array}{l}\text { Banyak material rusak yang } \\
\text { terabaikan }\end{array}$ & $\begin{array}{llrl}\text { Tidak } & \text { ada } & \text { regulasi } & \text { standar } \\
\text { dalam } & \text { proses } & \text { retur } & \text { barang } \\
\text { rusak } & & & \end{array}$ \\
\hline 4 & $\begin{array}{l}\text { Pekerja lapangan seringkali } \\
\text { harus bolak-balik gudang } \\
\text { untuk mendapatkan material }\end{array}$ & $\begin{array}{l}\text { Sistem lama tidak melakukan } \\
\text { pengawasan hingga rayon, hal } \\
\text { ini membuat pihak rayon hanya } \\
\text { akan menyediakan material } \\
\text { jika memang sangat } \\
\text { dibutuhkan }\end{array}$ \\
\hline 5 & $\begin{array}{l}\text { proses pengolahan data yang } \\
\text { lama dan tidak tertib } \\
\text { administrasi }\end{array}$ & $\begin{array}{l}\text { Terdapat rayon yang masih } \\
\text { mengandalkan Microsoft Excel }\end{array}$ \\
\hline 6 & $\begin{array}{l}\text { PT. PLN (Persero) Distribusi } \\
\text { Jawa Tengah dan D.I } \\
\text { Yogyakarta sulit untuk } \\
\text { melakukan pengawasan } \\
\text { hingga rayon }\end{array}$ & $\begin{array}{l}\text { Sistem pada area dan rayon } \\
\text { memiliki standar masing- } \\
\text { masing, tidak terintegrasi } \\
\text { mengerucut pada tingkat } \\
\text { distribusi sebagai sistem besar }\end{array}$ \\
\hline
\end{tabular}

\section{B. Analisis Kebutuhan}

Beberapa kebutuhan fungsional mengenai fitur yang harus dipenuhi dari Sistem Online Gudang adalah:

1) Adanya menu permintaan material

2) Adanya menu persetujuan permintaan

3) Adanya menu penjadwalan pengambilan

4) Adanya menu pengambilan material

5) Adanya menu pengeluaran material

6) Adanya menu penerimaan material

7) Adanya menu pemakaian material

8) Adanya menu penerimaan retur rayon

9) Adanya menu pengiriman retur ke area

10) Adanya menu penerimaan retur

11) Adanya menu lacak transaksi

12) Adanya menu untuk mengeloala data dokumentasi

13) Adanya menu pengaturan sistem mengenai hak akses pengguna 
Beberapa kebutuhan non fungsional perihal perangkat lunak yang di perlukan dalam pengembangan Sistem Online Gudang adalah:

1) Sistem Operasi : Microsoft Windows 7 professional 32 bit

2) Microsoft Visual Studio 2010

3) Oracle Database 11g Expres Edition

4) Editor Oracle : Toad for Oracle 9.7.2

5) Aplikasi web browser : Google Chrome, Mozilla firefox

\section{Desain Sistem}

Desain dalam pembangunan perangkat lunak merupakan upaya untuk mengonstruksi sebuah sistem yang memberikan kepuasan akan spesifikasi kebutuhan fungsional serta memenuhi target dan kebutuhan.

Desain sistem menggunakan metode Unified Modeling Language (UML). Perancangan sistem dalam bentuk diagram use case ditunjukkan pada Gambar 1 .

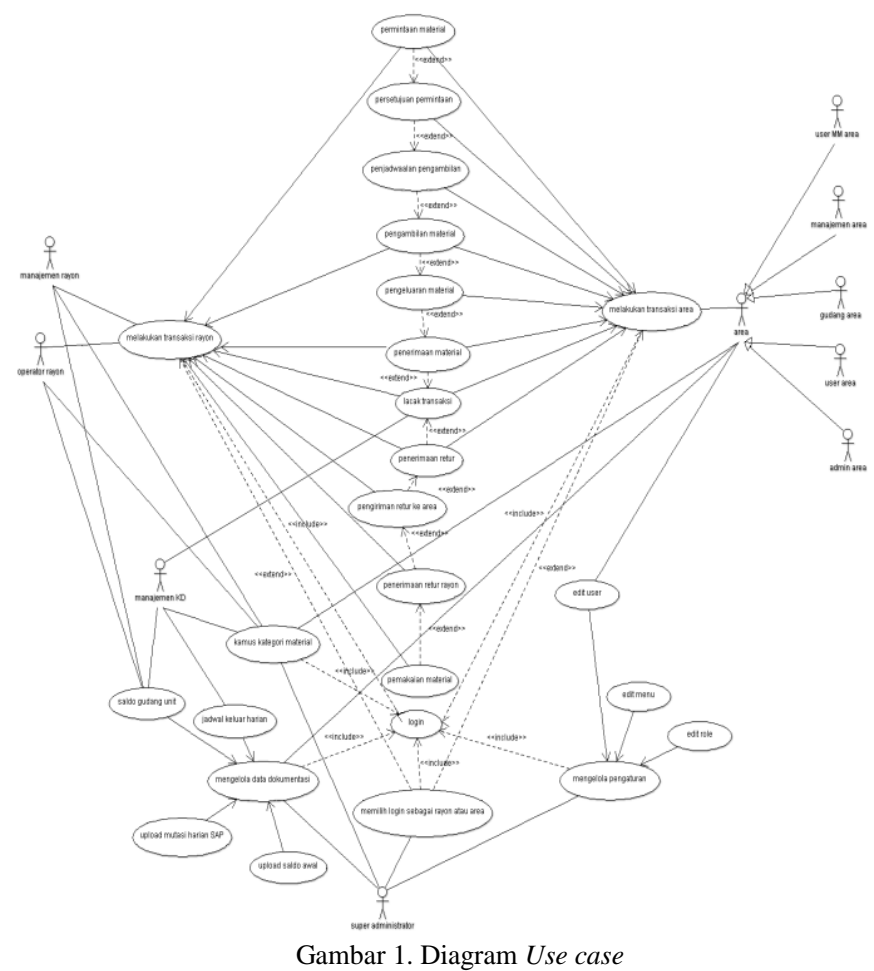

Perancangan sistem dalam bentuk diagram aktivitas ditunjukkan pada Gambar 2, Gambar 3, Gambar 4.

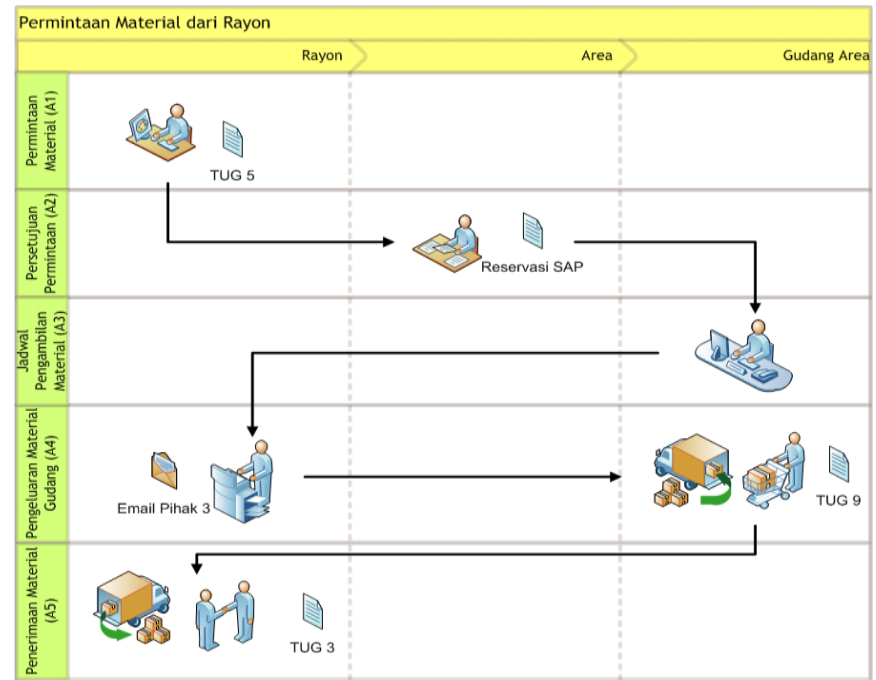

Gambar 2. Diagram aktivitas permintaan material dari rayon Jurnal Teknologi dan Sistem Komputer, Vol.3, No.1, Januari 2015 (e-ISSN: 2338-0403)
Gambar 2 menunjukkan proses pengadaan material pada rayon. Proses ini dimulai dari rayon yang mengirimkan permintaan (A1) ke area. Pada tingkat area permintaan akan disetujui (A2), jika disetujui maka permintaan akan dikirim ke pihak gudang area untuk mendapatkan jadwal pengambilan (A3). Ketika rayon mengambil material, pada pihak gudang area harus membuat laporan pengeluaran material (A4), jika sudah diterima, maka pihak rayon wajib memberikan laporan penerimaan material (A5).

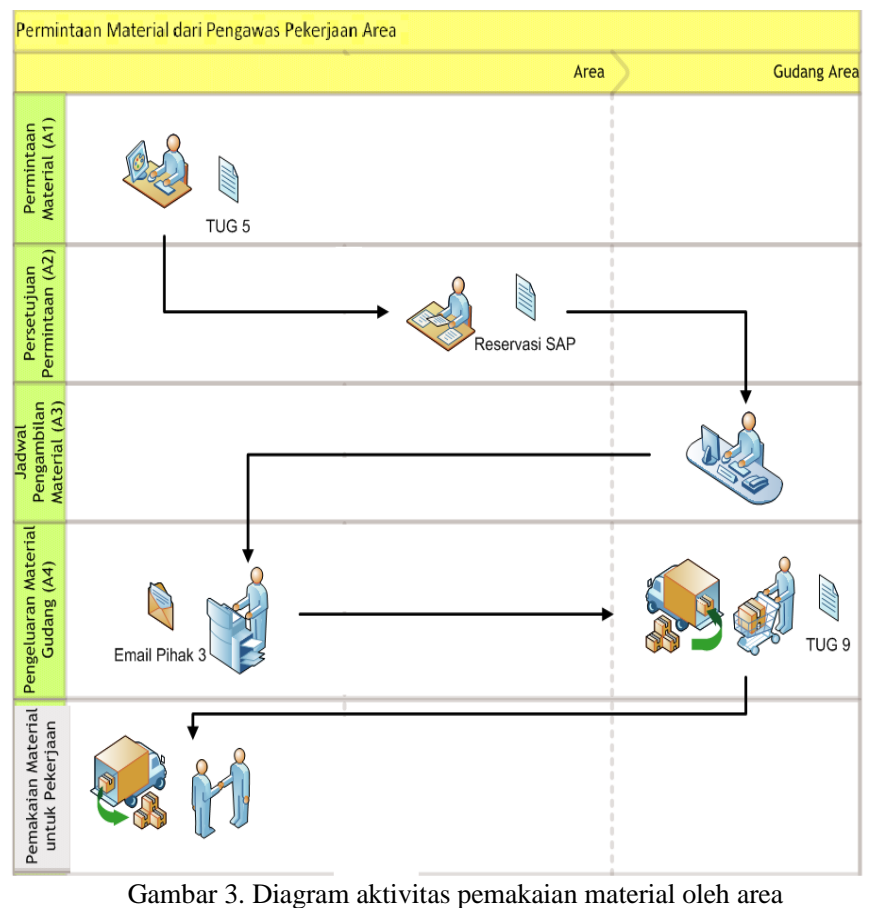

Gambar 3 menunjukkan proses pemakaian material oleh area. Proses ini dimulai ketika area mengirimkan permintaan material (A1) kepada pihak gudang area. ketika manajemen area sudah memberikan persetujuan (A2), maka transaksi dikirim ke gudang untuk ditentukan jadwal pengambilan (A3). Setelah mendapat jadwal, maka pihak area melakukan pengambilan material pada gudang dengan menunjukkan form pengambilan kepada gudang area untuk laporan pengeluaran (A4). Hingga proses ini, material dapat dipakai dalam proyek pekerjaan.

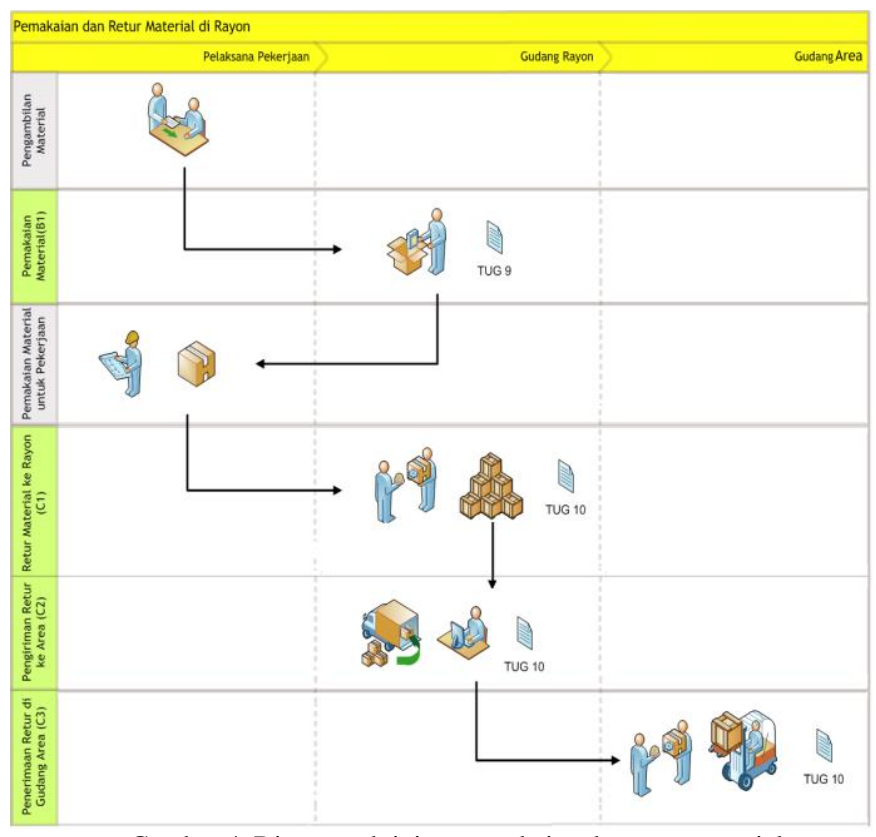

Gambar 4. Diagram aktivitas pemakaian dan retur material JTsiskom - 156 
Gambar 4 menunjukan proses pemakaian dan retur material. Proses ini dimulai ketika gudang rayon membuat laporan bahwa terjadi pemakaian material (B1) oleh pihak ketiga. Jika fakta di lapangan terjadi sisa ataupun kerusakan pada material, pihak ketiga memberikan laporan $(\mathrm{C} 1)$ kepada gudang rayon. Rayon kemudian mengirimkan material ke gudang asal, retur ke area (C2), hingga akhirnya material retur diterima oleh gudang area (C3).

Perancangan sistem dalam bentuk diagram kelas ditunjukkan pada Gambar 5.

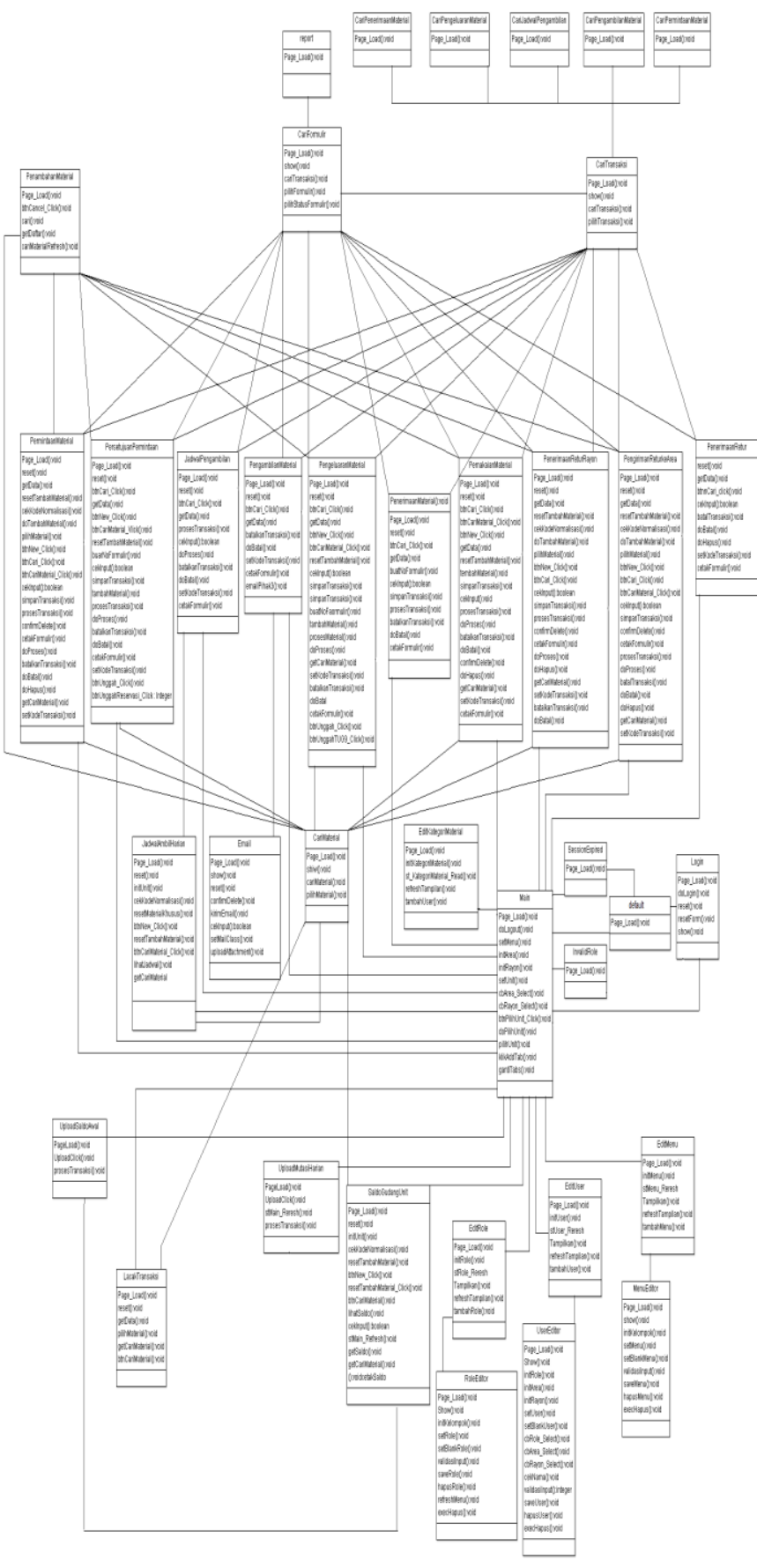

Gambar 5. Diagram Kelas
Perancangan sistem dalam bentuk diagram komunikasi ditunjukkan pada Gambar 6.

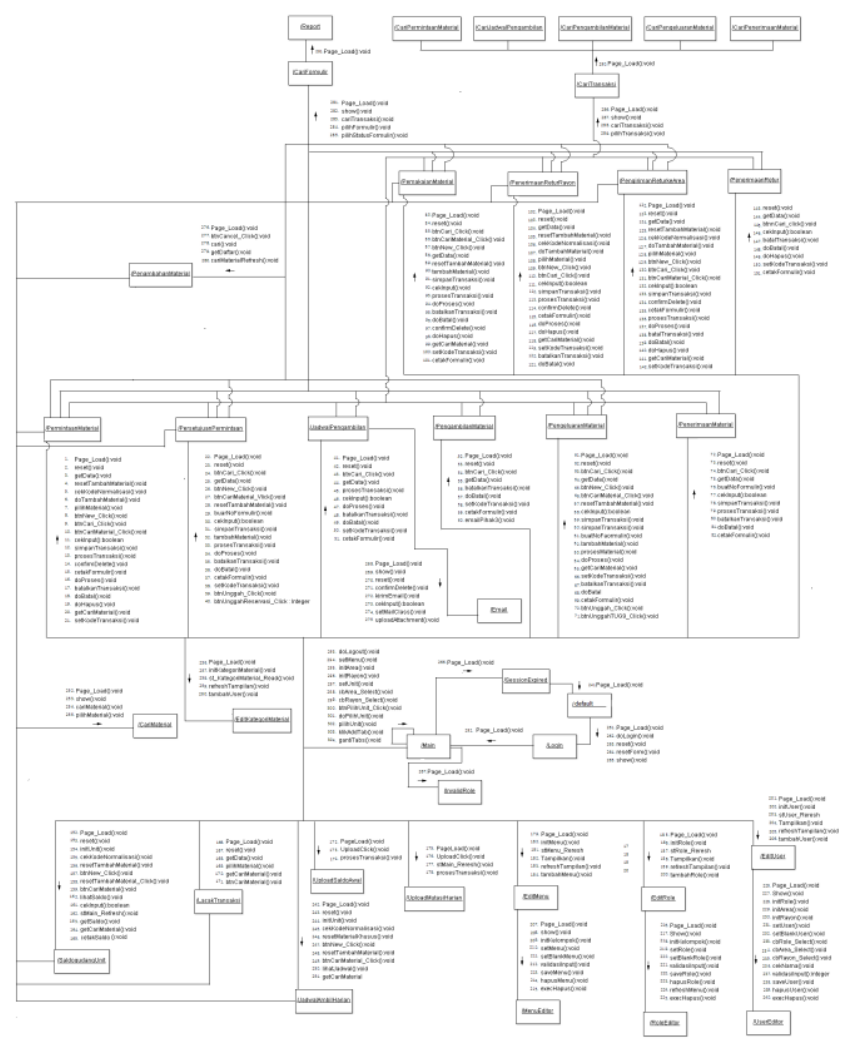

Gambar 6. Diagram komunikasi

\section{Desain Basis-Data}

Basis-data ialah tempat penyimpanan data sebuah sistem informasi. Tahap ini basis-data yang akan dibangun didesain dalam bentuk relasi tabel. Berikut diagram relasi tabel ditunjukkan pada Gambar 7.

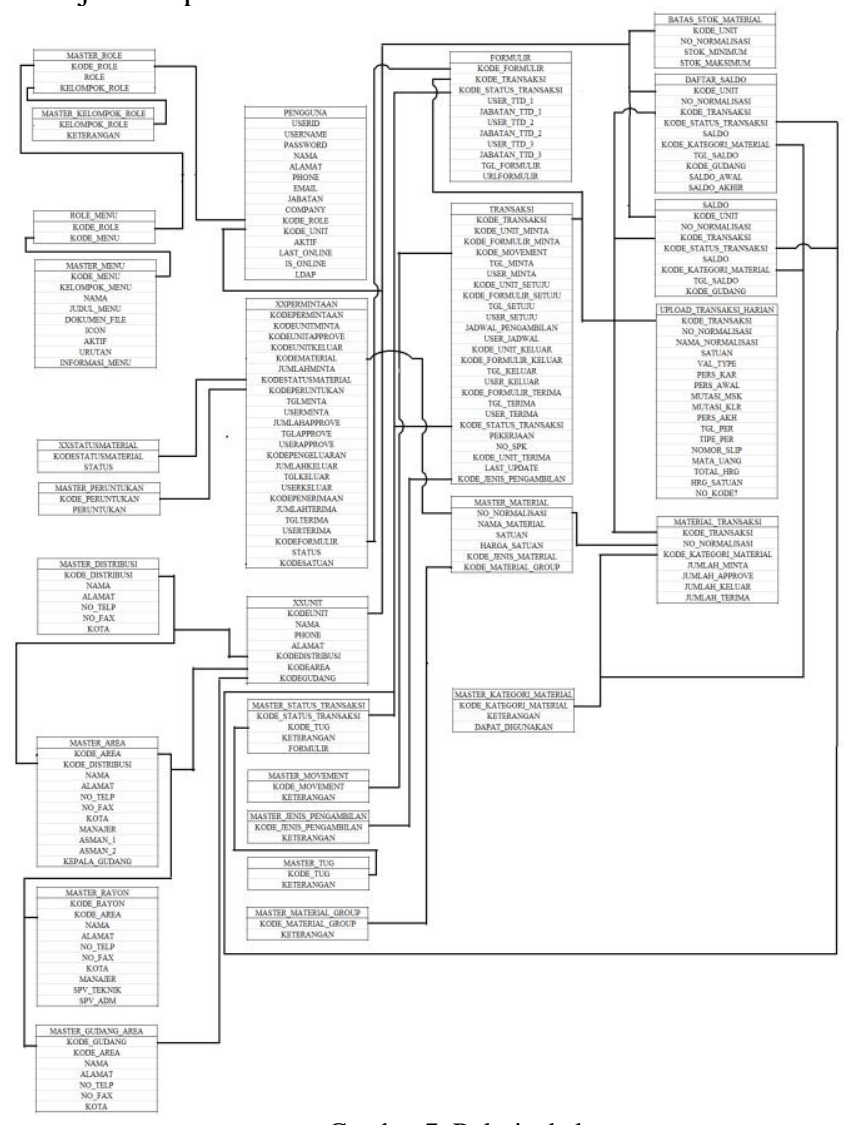

Gambar 7. Relasi tabel 


\section{IMPLEMENTASI DAN PENGUJIAN SISTEM}

\section{A. Implementasi Basis-data}

Berdasarkan atas perancangan basis-data pada diagram ERD sebelumnya, kemudian di implementasikan pada Oracle menggunakan Toad for Oracle sebagai editor. Beberapa diantaranya, sebagian tabel pada Sistem Online Gudang ditunjukkan pada Gambar 8, Gambar 9, dan Gambar 10.

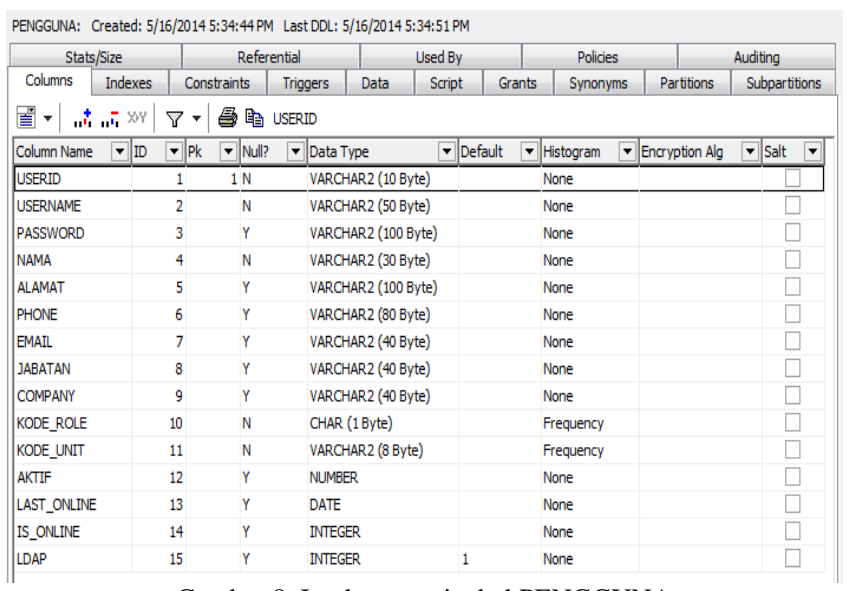

Gambar 8. Implementasi tabel PENGGUNA

SALDO: Created: 5/16/20145:34:45 PM Last DDL: 5/16/20145:34:51PM

\begin{tabular}{|c|c|c|c|c|c|c|c|c|c|c|c|c|}
\hline & Referential & & & & $\operatorname{sed} B y$ & & & Polices & & Auditing & & \\
\hline Columns & Indexes & Constra & & Triggers & Data & Script & Grants & Synony & \begin{tabular}{l|l} 
yms & Partitions
\end{tabular} & \begin{tabular}{l|l} 
s & Subpartitions
\end{tabular} & Stats/Size & \\
\hline 咸 $v "$ & 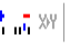 & $\nabla \cdot$ & 䁌 & & & & & & & & & \\
\hline Column Nam & & $\nabla I D$ & V pk & \begin{tabular}{l|l}
$\mathrm{k}$ V Null? \\
\end{tabular} & & ata Type & 7 & Default & - Histogram & V Encryption Alg & $\nabla$ Salt & $\nabla$ \\
\hline KODE_UNTT & & & 1 & $Y$ & & ARCHAR2 & 5 Byte) & & None & & $\square$ & ] \\
\hline NO NORMA & LISASI & & 2 & Y & & ARCHAR2( & 6 Byte) & & None & & $\square$ & \\
\hline KODE_TRAI & SAKSI & & 3 & Y & & ARCHAR2 & 6 Byte) & & None & & $\square$ & \\
\hline KODE_STAT & US_TRANSAK & & 4 & Y & & ARCHAR2( & Byte) & & None & & $\square$ & \\
\hline SALDO & & & 5 & N & & UMBER & & & None & & $\square$ & \\
\hline KODE_KATE & GORI_MATER & & 6 & y & & ARCHAR2 & Byte) & & None & & $\square$ & \\
\hline TGL_SALDO & & & 7 & Y & & ATE & & & None & & $\square$ & \\
\hline KODE_GUD & & & 8 & Y & & ARCHAR2( & (Byte) & & None & & $\square$ & \\
\hline
\end{tabular}

Gambar 9. Implementasi tabel SALDO

TRANSAKS: Created: 5/16/2014 5:34:46 PM Last DDL: 5/16/2014 5:34:51 PM

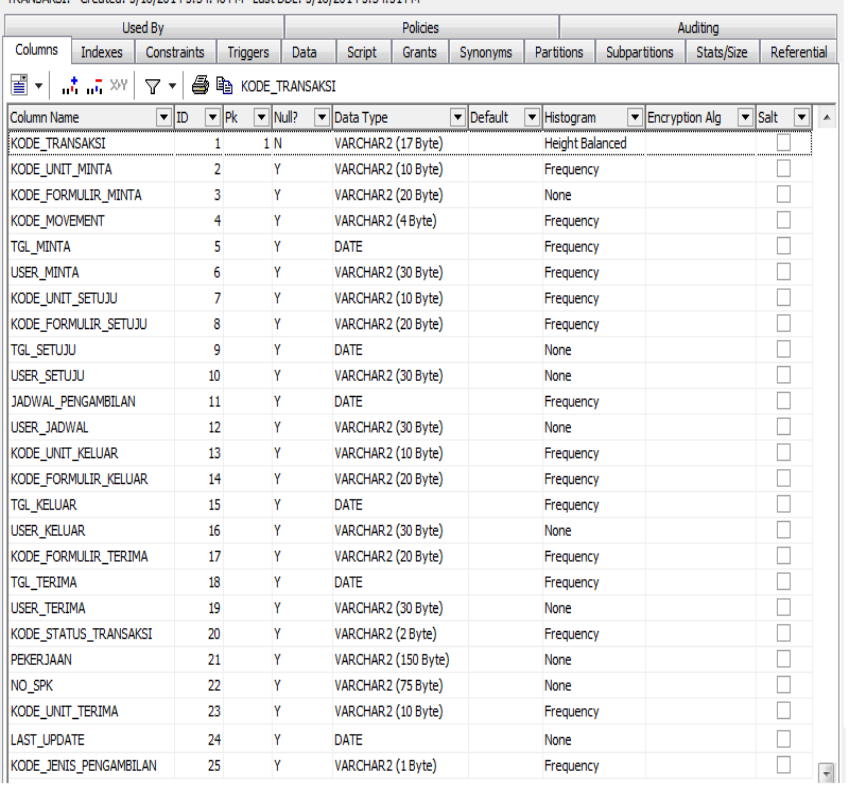

Gambar 10. Implementasi tabel TRANSAKSI

\section{B. Implementasi Antarmuka}

Implementasi antarmuka merupakan tahap membangun tampilan sistem.

Gambar 11 merupakan tampilan dari antarmuka login yang merupakan halaman default sistem untuk validasi pengguna

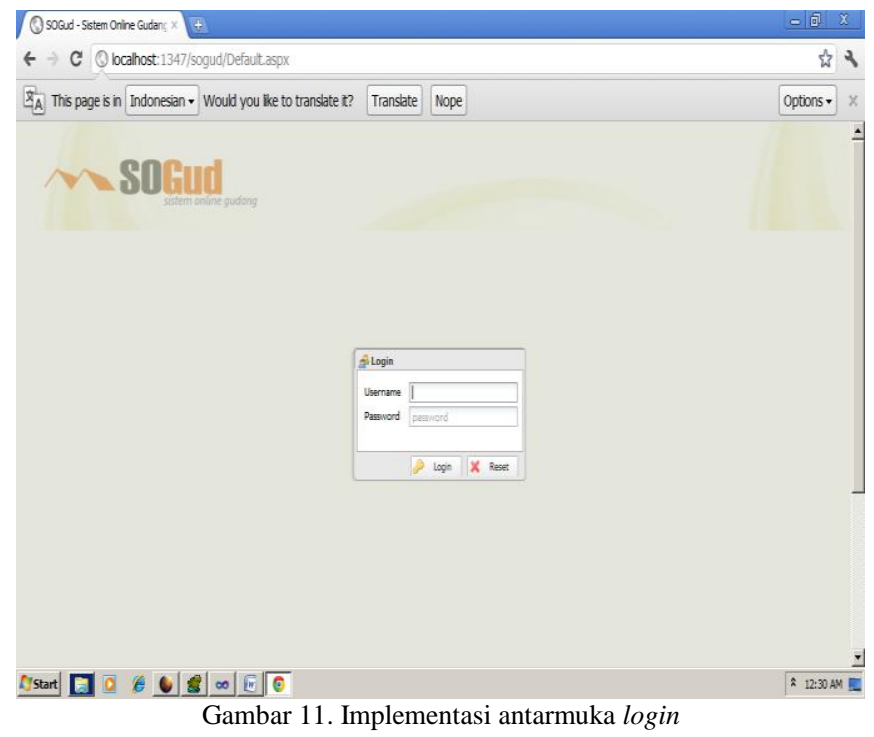

Gambar 12 menunjukkan antarmuka Permintaan Material. Pada antarmuka ini pengguna dapat mengirimkan permintaan material yang dibutuhkan, dengan cara mengisi form pada kotak teks yang ada, memilih material untuk kemudian diproses ke area.

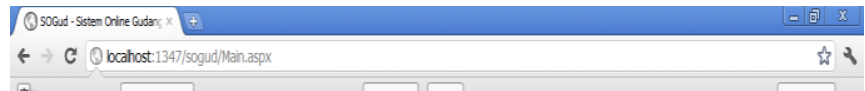

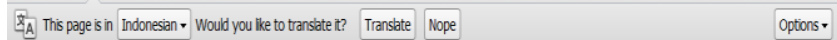

\section{SOGud}

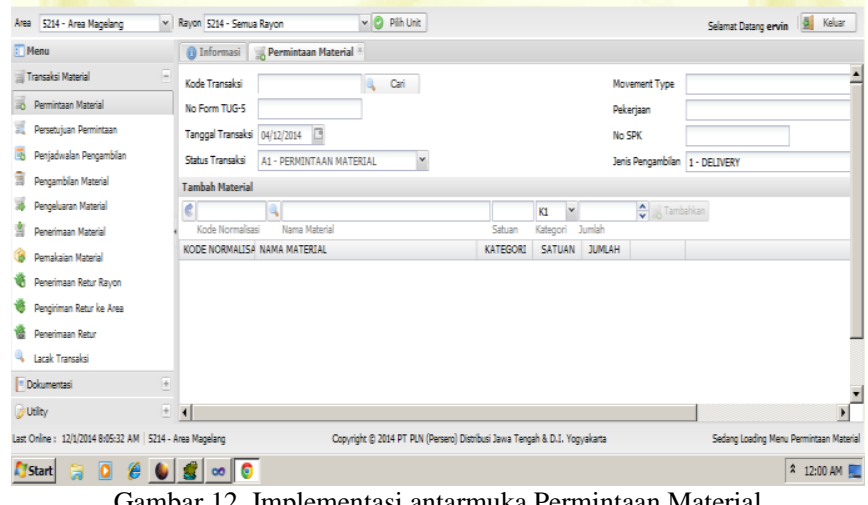

Gambar 13 menunjukkan antarmuka Peretujuan Permintaan. Pada antarmuka ini pengguna memberikan persetujuan atas permintaan. Permintaan yang disetujui akan mendapatkan nomor formulir dan nomor reservasi, selanjutnya siap diproses ke gudang. 


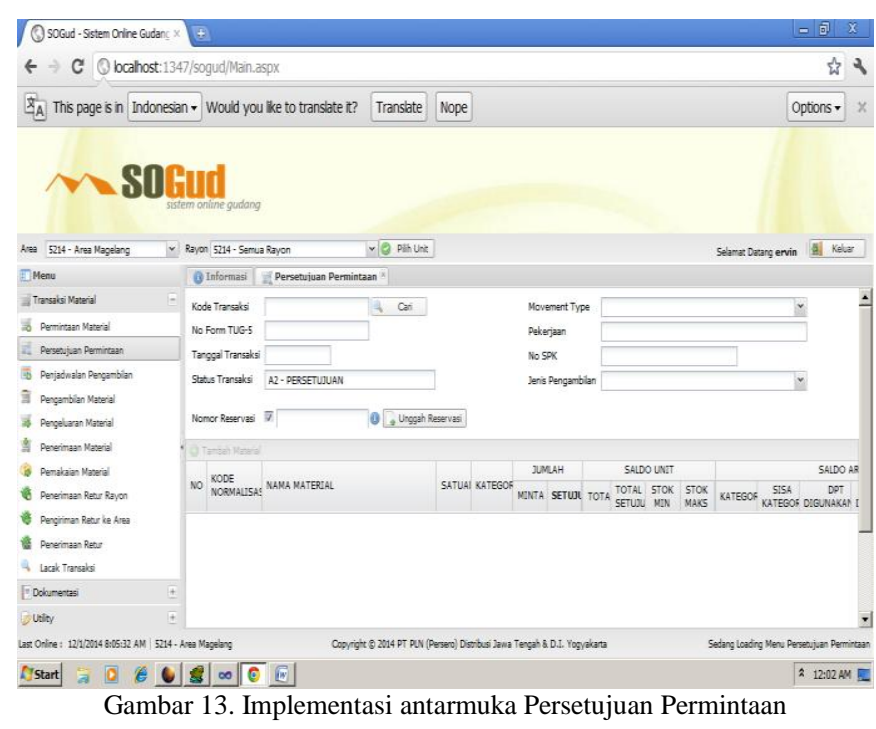

Gambar 14 menunjukkan antarmuka Pemakaian Material. Antarmuka ini berfungsi untuk mencatat setiap pemakaian barang.

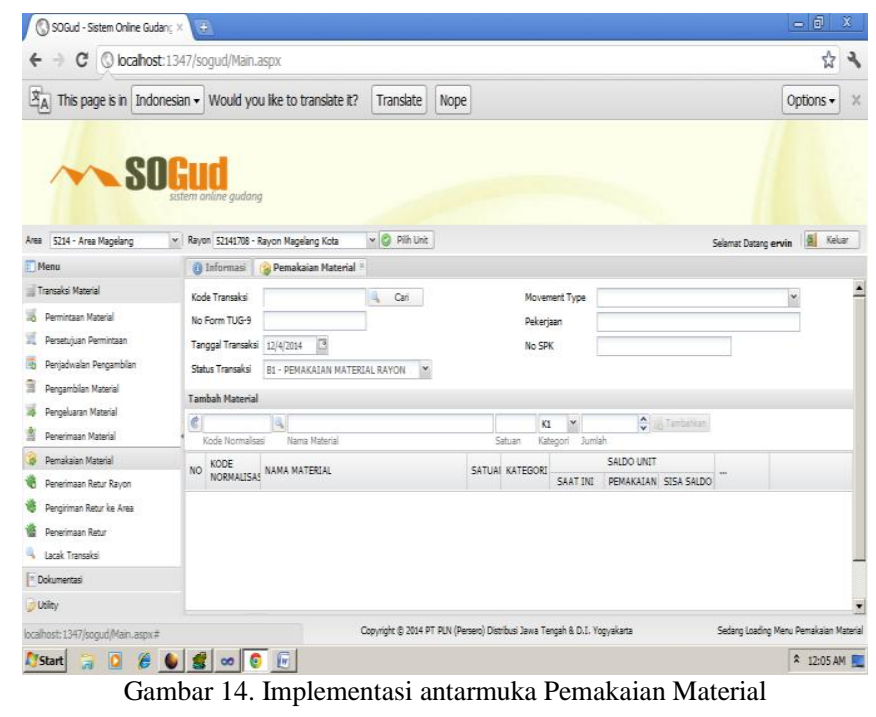

Gambar 15 menunjukkan antarmuka Edit User. Antarmuka edit user digunakan untuk mengelola data pengguna meliputi menambahkan dan mengubahnya

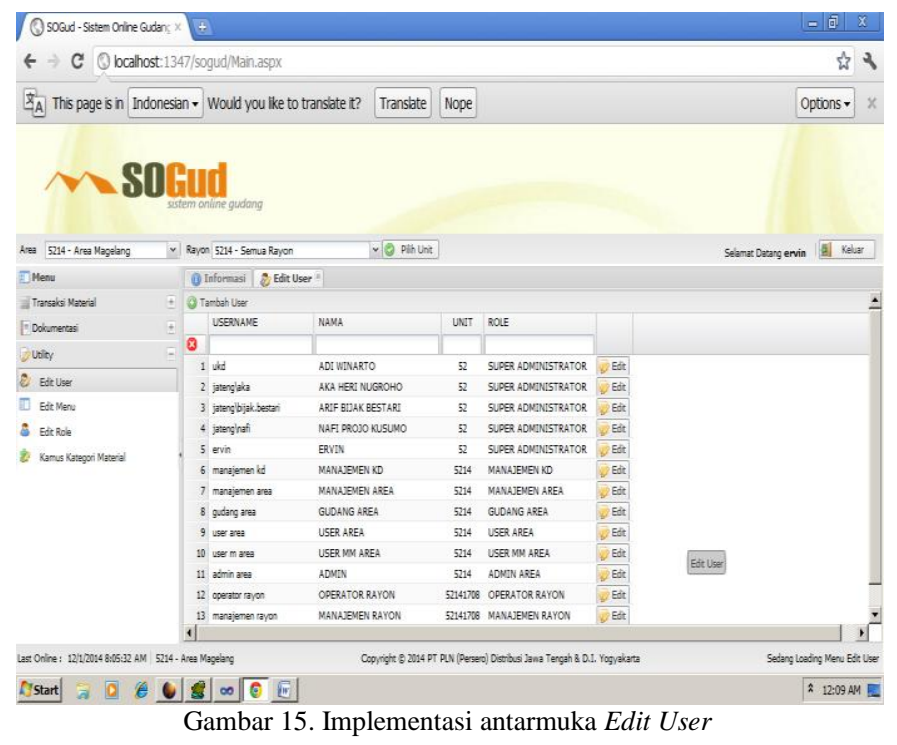

\section{Pengujian Sistem}

Pengujian dilakukan pada beberapa fungsi dari Sistem Online Gudang. Fungsi yang diuji dikelompokkan berdasarkan menu, yang kemudian disebut sebagai kelompok uji. Berikut hasil pengujian ditunjukkan oleh Tabel 2.

TABEL 2

TABEL HASIL UJI

\begin{tabular}{|l|l|c|}
\hline \multicolumn{1}{|c|}{ Kelompok Pengujian } & \multicolumn{1}{c|}{ Metode } & Hasil \\
\hline Permintaan material & Black Box & Sukses \\
\hline Persetujuan permintaan & Black Box & Sukses \\
\hline Penjadwalan pengambilan & Black Box & Sukses \\
\hline Pengambilan material & Black Box & Sukses \\
\hline Pengeluaran material & Black Box & Sukses \\
\hline Penerimaan material & Black Box & Sukses \\
\hline Pemakaian material & Black Box & Sukses \\
\hline Penerimaan retur rayon & Black Box & Sukses \\
\hline Pengiriman retur ke area & Black Box & Sukses \\
\hline Penerimaan retur & Black Box & Sukses \\
\hline Lacak transaksi & Black Box & Sukses \\
\hline Saldo gudang unit & Black Box & Sukses \\
\hline Jadwal keluar harian & Black Box & Sukses \\
\hline Upload saldo awal & Black Box & Sukses \\
\hline Upload mutasi harian SAP & Black Box & Sukses \\
\hline Edit user & Black Box & Sukses \\
\hline Edit menu & Black Box & Sukses \\
\hline Edit role & Black Box & Sukses \\
\hline Kamus kategori material & Black Box & Sukses \\
\hline
\end{tabular}

\section{KESIMPULAN DAN SARAN}

\section{A. Kesimpulan}

Berdasarkan hasil penelitian, maka dapat diambil ksimpulan sebagai berikut.

1) Sistem Online Gudang sudah sesuai Standar Operasional Prosedur (SOP) pada PT. PLN (Persero).

2) Sistem Online Gudang merupakan aplikasi web berbasis ASP.Net dengan Microsoft Visual Studio sebagai development tools dan Oracle sebagai relational data base management sistem (RDBMS)

3) Pihak distributor, area, hingga rayon dapat terhubung pada Sistem Online Gudang, dan dapat mengaksesnya sesuai dengan hak akses yang berdasar pada tugas dan kewenangannya seperti yang diharapkan.

4) Berdasarkan pengujian Black Box, fungsi-fungsi pada Sistem Online Gudang sudah berjalan seperti ang diharapkan. Namun masih diperlukan proses maintenance untuk kesempurnaan sistem di masa mendatang.

B. Saran

Melihat dari beberapa kekurangan terhadap hasil penelitian, terdapat beberapa saran sebagai berikut.

1) Perlu dilakukan penelitian lebih lanjut untuk mengembangkan Sistem Online Gudang dalam rangka memenuhi keinginan dan kebutuhan pengguna.

2) Sistem notifikasi yang saat ini masih kurang, maka diperlukan pengembangan lebih lanjut sehingga Sistem Online Gudang dapat memberikan pemberitahuan secara cepat. 


\section{DAFTAR PUSTAKA}

[1] ---, Gudang Online Swalayan Area Tanjung Priok.ppt, Jakarta, 2013.

[2] A.S Rosa, M, Shalahuddin, Modul Rekayasa Perangkat Lunak (Terstruktur dan Berorientasi Objek), Modula Bandung, Bandung, 2009.

[3] Booch, G, Rumbaugh, J, dan Jacobson, I, The Unified Modelling Language User Guide SECOND EDITION, Pearson Education, United State, 2005.

[4] Bunawan, dan D, Suryadi H.S, Pengantar Siklus Pengembangan Sistem Informasi, Gunadharma, Jakarta, 1996.

[5] David, M, Kroenke, Database Processing Jilid 1 edisi, Erlangga.

[6] Julius, Hermawan, Analisis Desain \& Pemrograman Berorientasi Obyek dengan UML dan Visual Basic.NET.

[7] Kartawijaya, Edi, Analisa dan Perancangan Sistem Informasi Aplikasi WMS, Tugas Akhir S-1, Universitas Mercu Buana, 2011.

[8] M, Farid Azis, Object Oriented Programming Php 5, Elex Media Komputindo, Jakarta

[9] Modell, Martin E, A Profesional, 1987.

[10] Nugroho, Adi, Perancangan dan Implementasi Sistem Basis Data, Andi, Yogyakarta, 2011.

[11]

Permana, Agus, Konsep Bahasa C\#,

http://agusp3rmana.wordpress.com. Maret 2014.

[12] Pressman, Roger S, Rekayasa Perangkat Lunak (Pendekatan Praktis), Andi, Yogyakarta, 2002.

[13] Prijono, Benny L, Pengenalan Administrasi Oracle Database, 1997.

[14] Santoso, Harip, VB.Net untuk .NET Programmer, Elex Media Komputindo, Jakarta, 2011

[15] Shara, Harianja, Rani,Model Pengembangan Sistem Informasi Berbasis Web, http://hanikoasahara.blogspot.com, Maret 2014

[16] www.pln.co.id, Maret 2014.

[17] Rifai, ahmad. Rancang Bangun Sistem Persediaan (Inventory) dengan Model Software As A Service Menggunakan Service Oriented Architecture. Jurnal. Sepuluh November.

[18] Meilani, Difana. Perancangan Sistem Informasi Manajemen Persediaan Studi Kasus : PDAM Tirta Sakti Kabupaten Kerinci. Jurnal. Universitas Andalas.

[19] Saputro, Wahyu hadi. Pengembangan Sistem Informasi Persediaan Bahan Baku Pada PT. Lembalindo Tirta Anugerah. Jurnal. Universitas Islam Negeri Syarif Hidayatulloh. 